\title{
Sublingual misoprostol and hyperpyrexia: case report with temperature curve
}

\author{
Paul Nkemtendong Tolefac ${ }^{1,2^{*}}$ and Jacqueline Ze Minkande ${ }^{2}$
}

\begin{abstract}
Background: Misoprostol has a wide range of applications in obstetrics and gynaecology. It is widely recommended by WHO, FIGO and ACOG for the treatment of postpartum haemorrhage due to it safety and cost-effectiveness. However, usage might be associated to hyperpyrexia and shivering.

Case presentation: We present a 30 year old Cameroonian female gravida 1 para 1 who had a vaginal delivery at 40 weeks of gestation complicated by primary postpartum haemorrhage (PPH). PPH was managed by sublingual misoprostol that induced shivering and hyperpyrexia managed successfully with paracetamol and cooling.

Conclusions: The occurrence of fever and shivering should be kept in mind when administering misoprostol for PPH. Keywords: Misoprostol, Hyperpyrexia, Temperature, Case report
\end{abstract}

\section{Background}

Postpartum haemorrhage $(\mathrm{PPH})$ remains the most common cause of maternal mortality with uterine atony being the commonest underling aetiology [ 1 , 2]. It accounts for nearly one-quarter of all maternal deaths worldwide and an estimated 125,000 deaths occur each year [1]. About $50 \%$ of these deaths occur in sub-Sahara Africa alone [3]. Researchers have for decades searched the safest, fastest and most effective pharmacological agents to manage this dreaded complication [4]. Conventional uterotonics such as oxytocin have been the drug of choice in the first line management of PPH secondary to uterine atony. However, a major short coming has been its obligate parenteral route of administration $[2,5]$.

Misoprostol is an attractive alternative because of its uterotonic potency, multiple convenient routes of administration and stability at ambient temperatures [6]. The most common side effects associated with the postpartum administration of misoprostol are shivering

\footnotetext{
*Correspondence: ptolefac15@gmail.com

${ }^{2}$ Intern Faculty of Medicine and Biomedical Sciences, University of Yaoundé 1, Yaounde, Cameroon

Full list of author information is available at the end of the article
}

and pyrexia [7]. Studies show the rates of shivering and fever to be related to the dose and route of administration. Higher rates of shivering and elevated body temperature are associated with oral and sublingual routes of administration, which achieve a higher and faster maximum plasma concentration than vaginal and rectal routes [6-8]. We report the case of a 30 year old Cameroonian female gravida 1 para 1 who had a vaginal delivery at 40 weeks of gestation complicated by primary postpartum haemorrhage (PPH). PPH was managed by sublingual misoprostol that induced shivering and hyperpyrexia managed successfully with paracetamol and cooling.

\section{Case report}

A 30 year old female Cameroonian gravida 1 para 1 at 40 weeks of gestation with an uneventful antenatal consultation presented at the active phase of labour with a cervical dilatation of $4 \mathrm{~cm}$ and good uterine contractions. Labour progressed normally $5 \mathrm{~h}$ later to the vaginal delivery of a live female baby with weight $2820 \mathrm{~g}$ and Apgar 8/10 and 10/10 at the first and 5th min respectively. Blood loss after delivery was estimated at $350 \mathrm{cc}$. Whilst active management of the third stage of labour 
was done with injection of $10 \mathrm{IU}$ of oxytocin, the placenta was delivered, examined and found to be complete. At the end of the third stage of labour, the uterus was well contracted and globular. Patient was then transferred to the ward in a haemodynamically stable condition following $2 \mathrm{~h}$ of monitoring. Ten hours later and after evaluation she complained of abundant lochia associated with vertigo and physical examination revealed blood pressure $102 / 77$, heart rate of 104 beats/ min and temperature of $37.6{ }^{\circ} \mathrm{C}$. The uterus was tender and poorly contracted, other aspects of the examination were normal. We concluded on mild uterine atony and placed $600 \mu \mathrm{g}$ of misoprostol sublingual. $20 \mathrm{~min}$ later we were called for sudden shivering and cold sensation. The temperature measured was $37.2{ }^{\circ} \mathrm{C}$, an hour later the temperature rose to $38.6{ }^{\circ} \mathrm{C}$ and two hours later to $39.7^{\circ} \mathrm{C}$ (Fig. 1 showed temperature variations over $18 \mathrm{~h}$ ). There was no dyspnoea, no itching, no rashes, no convulsion and no angioedema. Vital signs were stable and there was no cardiopulmonary distress. We concluded on a working diagnosis of hyperpyrexia from misoprostol. Emergency full blood count and C-reactive protein (CRP) were normal. The management consisted of paracetamol $1 \mathrm{~g} 6$ hourly and cooling the patient via tepid sponging. Paracetamol and cooling were started 1 and $3 \mathrm{~h}$ respectively after misoprostol administration. Twelve hours later the temperature dropped and remained less than $38{ }^{\circ} \mathrm{C}$ and she was monitored for another $24 \mathrm{~h}$ and discharged.

\section{Discussion}

Misoprostol, a synthetic prostaglandin E1 analogue originally used for the treatment of NSAID induced peptic ulcer has been found to have a wider application in the field of obstetrics and gynaecology because of its uterotonic and cervical-maturation effects [6]. It has been recommended for the treatment and prevention of $\mathrm{PPH}$ by ACOG, FIGO and WHO [9-11]. Compared to other uterotonics, misoprostol is cheap, readily available, has a longer shelf life, stable at ambient temperature, and can be administered easily. It is a very safe drug associated with transient, mild side-effects like fever, chills, nausea, vomiting, diarrhoea and abdominal pain [6]. Collective total daily doses of $1600 \hat{\mathrm{A}} \mu \mathrm{g}$ have been tolerated with only mild gastrointestinal discomfort [6]. A study done in Ecuador in 2010 showed that there was a sharp increase in temperature within $1 \mathrm{~h}$ of treatment, a peak in temperature $1-2 \mathrm{~h}$ post-treatment, and a gradual decline in temperature over a period of $3 \mathrm{~h}$. Average temperatures remained above $40.0^{\circ} \mathrm{C}$ for less than $2 \mathrm{~h}$, and measured below $38.0{ }^{\circ} \mathrm{C}$ approximately $6 \mathrm{~h}$ after receiving misoprostol. In our indexed case shivering started $20 \mathrm{~min}$ after administration and the temperature started rising $1 \mathrm{~h}$ later reaching a peak of $40.3{ }^{\circ} \mathrm{C} 4 \mathrm{~h}$ later and dropping to less than $38.0{ }^{\circ} \mathrm{C} 12 \mathrm{~h}$ later. This was consistent with results of recent studies $[4,12]$. Temperature elevations associated with the use of misoprostol are compatible with the hypothalamic adjustment. Prostaglandins E2 (PGE2) have been involved in the pathophysiological

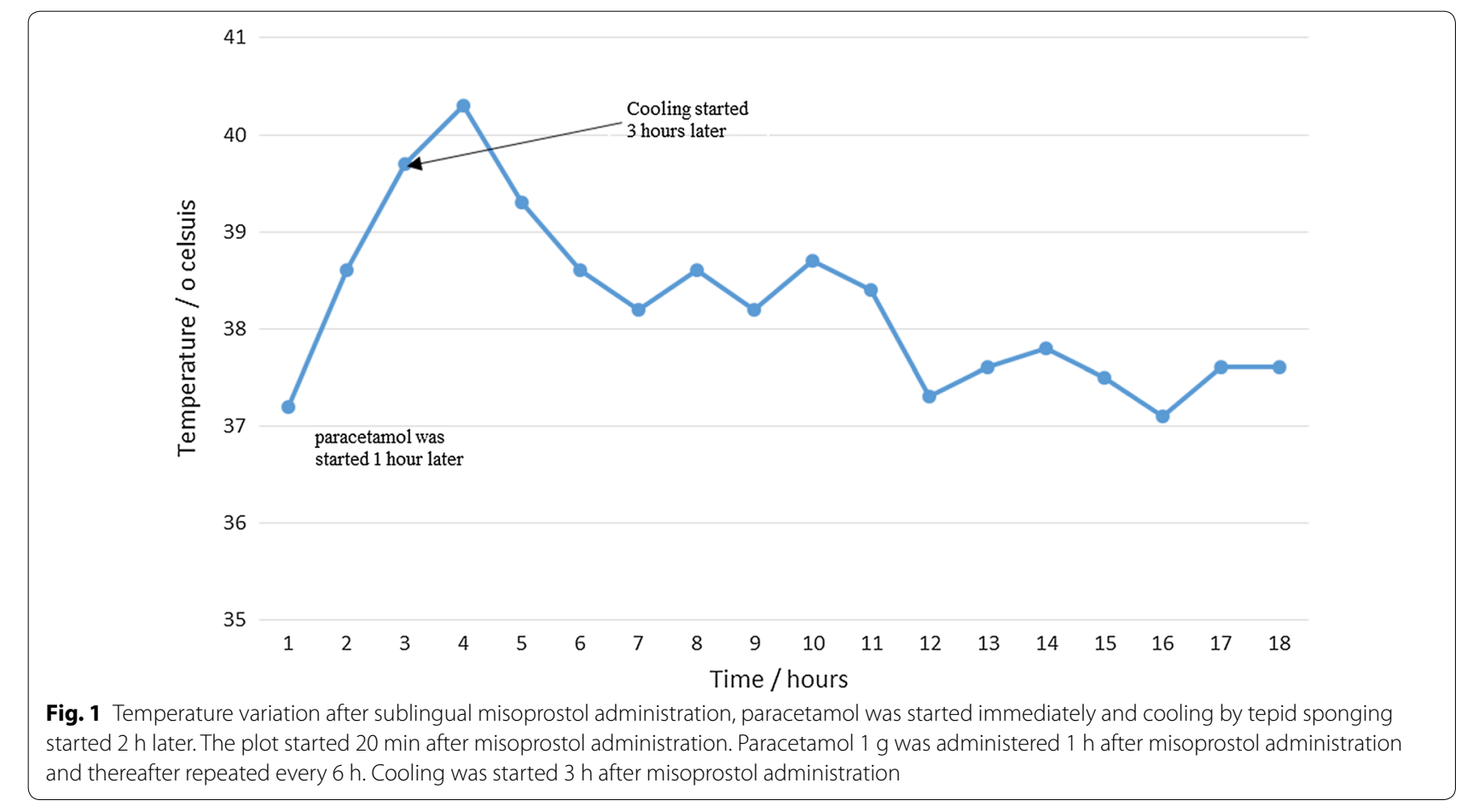


mechanism of endogenous fever and identified as the major mediator for inducing fever because of its interaction with the Prostaglandin E3 (PGE3) receptor. Misoprostol-induced fever mimics the PGE2 endogenous thermoregulation patterns, changing the hypothalamic adjustment in its upper segment and stimulating temperature elevation [4]. In our patient the possibility of a postpartum infection was almost zero as our patient had no risk factor such as prolong labour, premature rupture of membranes, etc. and emergency CRP and FBC had values within normal ranges. The fever is usually treated with paracetamol, anti-inflammatory and cooling $[4,12]$. In our indexed case we used paracetamol and cooling and there was a good clinical response with temperature remaining less than $38^{\circ} \mathrm{C}$ after $12 \mathrm{~h}$ (see Fig. 1).

\section{Conclusion}

Hyperpyrexia associated with shivering may be associated with administration of misoprostol $600 \mu \mathrm{g}$, this is more common after sublingual administration. Treatment is with oral paracetamol and cooling. This common side effect should be kept in mind when administering misoprostol for postpartum haemorrhage.

\section{Authors' contributions}

PNT managed the case, PNT \& JZM wrote the draft manuscript, PNT \& JZM corrected the original manuscript. Both authors read and approved the final manuscript.

\section{Author details}

1 Douala General Hospital, Douala, Cameroon. ${ }^{2}$ Intern Faculty of Medicine and Biomedical Sciences, University of Yaoundé 1, Yaounde, Cameroon.

\section{Acknowledgements}

We express our sincere gratitude to all doctors, nurses and medical students who took part in the management of the patient. We sincerely thank Dr. Calypse Ngwasiri for proof reading the manuscript for language and spelling checks.

\section{Competing interests}

The authors declare that they have no competing interests" in this section.

\section{Availability of data and materials}

The datasets (details of all results) are available from the corresponding author on reasonable request.

\section{Consent for publication}

Written informed consent was obtained from the patient's for publication of this case report and any accompanying images. A copy of the written consent is available for review by the Editor-in-Chief of this journal.

\section{Ethics approval and consent to participate}

Ethical approval was obtained from Douala general hospital for publication of this case report.
Funding

None.

\section{Publisher's Note}

Springer Nature remains neutral with regard to jurisdictional claims in published maps and institutional affiliations.

Received: 2 May 2017 Accepted: 21 July 2017

Published online: 26 July 2017

\section{References}

1. Hogan MC, Foreman KJ, Naghavi M, Ahn SY, Wang M, Makela SM, et al. Maternal mortality for 181 countries, 1980-2008: a systematic analysis of progress towards Millennium Development Goal 5. Lancet Lond Engl. 2010;375(9726):1609-23.

2. Bonnet MP, Benhamou D. Management of postpartum haemorrhage. F1000Res. 2016. http://www.ncbi.nlm.nih.gov/pmc/articles/ PMC4926727/. Accessed 28 Apr 2017.

3. Tebeu P-M, Halle-Ekane G, Da Itambi M, Mbu RE, Mawamba Y, Fomulu JN. Maternal mortality in Cameroon: a university teaching hospital report. Pan Afr Med J. 2015. http://www.ncbi.nlm.nih.gov/pmc/articles/ PMC4561158/. Accessed 28 Apr 2017.

4. Durocher J, Bynum J, León W, Barrera G, Winikoff B. High fever following postpartum administration of sublingual misoprostol. BJOG. 2010;117(7):845-52.

5. Mousa HA, Blum J, Abou El Senoun G, Shakur H, Alfirevic Z. Treatment for primary postpartum haemorrhage. Cochrane Database Syst Rev. 2014;(2):CD003249.

6. Allen $\mathrm{R}, \mathrm{O}$ 'Brien $\mathrm{BM}$. Uses of misoprostol in obstetrics and gynecology. Rev Obstet Gynecol. 2009;2(3):159-68.

7. Khan RU, El-Refaey H. Pharmacokinetics and adverse-effect profile of rectally administered misoprostol in the third stage of labor. Obstet Gynecol. 2003;101(5 Pt 1):968-74.

8. Al-Harazi AH, Frass KA. Sublingual misoprostol for the prevention of postpartum hemorrhage. Saudi Med J. 2009:30(7):912-6.

9. American College of Obstetricians and Gynecologists. ACOG Practice Bulletin: Clinical Management Guidelines for Obstetrician-Gynecologists Number 76, October 2006: postpartum hemorrhage. Obstet Gynecol. 2006;108(4):1039-47.

10. FIGO guideline. Treatment of postpartum haemorrhage with misoprostol. 2012.

11. Hofmeyr GJ, Gülmezoglu AM, Novikova N, Linder V, Ferreira S, Piaggio G. Misoprostol to prevent and treat postpartum haemorrhage: a systematic review and meta-analysis of maternal deaths and dose-related effects. Bull World Health Organ. 2009;87(9):666-7.

12. León W, Durocher J, Barrera G, Pinto E, Winikoff B. Dose and side effects of sublingual misoprostol for treatment of postpartum hemorrhage: what difference do they make? BMC Pregnancy Childbirth. 2012;12:65.

Submit your next manuscript to BioMed Central and we will help you at every step:

- We accept pre-submission inquiries

- Our selector tool helps you to find the most relevant journal

- We provide round the clock customer support

- Convenient online submission

- Thorough peer review

- Inclusion in PubMed and all major indexing services

- Maximum visibility for your research

Submit your manuscript at www.biomedcentral.com/submit 